\title{
Transnational Drug Trafficking: Studi Kasus Peningkatan Peredaran Narkotika di Bangladesh
}

\author{
Bayu Arif Ramadhan', Mubaimin Zulhair Achsin ${ }^{2}$ \\ Universitas Brawijaya
}

\begin{abstract}
Drug trafficking is one of the numerous acts of transnational criminal organizations (TOC). Bangladesh upon the course of 2015- 2017, had suffered from the intense drug flow, especially from the type of Yaba/amphetamine-type stimulant (ATS) in which peaked itself in 2015 by $211,2 \%$ percentage comparing to the previous years according to Drug Narcotics Control (DNC) reports and various media outlets. These flows were suspiciously running from the neighborhood country from Bangladesh, Myanmar, due to the unavailability of domestic yaba/ATS producers within Bangladesh. Contradict to the prevailing course of domestic anti-drug law in Bangladesh as embodied within the Drug Narcotics Act 2002, which tries to curb and prohibit whole activities regarding drug trafficking or flow. Therefore the writer was curious to conduct further research to examine the factors available to influence the intensity of drug trafficking and flow in Bangladesh upon 2015-2017.
\end{abstract}

Keywords: TOC. Narcotics Trafficking, Bangladesh, Yaba/ ATS. Myanmar, 2015-2017

\section{PENDAHULUAN}

Perkembangan fenomena globalisasi yang ditandai dengan kemajuan pesat berbagai aspek seperti teknologi, transportasi, informasi, dan komunikasi, mengakibatkan timbulnya kerentanan negara-negara di dunia akan terjadinya ancaman keamanan bersifat kontemporer seperti kejahatan transnasional atau Transnational Organized Crime (TOC) (Williams, 1998). Kerentanan ini timbul akibat melemahnya otoritas suatu negara terhadap batas (border) antar negara sebagai dampak globalisasi yang mengakibatkan terbukanya akses keluar masuk dari manusia dan barang baik yang bersifat legal dan sebaliknya bersifat ilegal.

Aktivitas TOC tidak hanya mengancam entitas negara tertentu, melainkan juga menjadi ancaman kepada negara-negara sekitarnya, kawasan, sampai dengan lingkup internasional. Sebagaimana menurut Konvensi Palermo Artikel 2(a) aktivitas TOC dapat dijelaskan sebagai aktivitas kriminal yang dilaksanakan secara terorganisir, dalam waktu yang lama, bertujuan untuk mendapatkan keuntungan finansial langsung maupun tidak langsung, dilaksanakan di lebih dari satu negara, dilaksanakan di suatu negara namun dikendalikan dari negara lain, sampai dengan dilaksanakan di suatu negara namun menimbulkan dampak terhadap negara lain (UNODC, n.d.) meliputi berbagai macam aktivitas seperti peredaran narkotika sampai dengan pencucian uang (Williams, 1998). Aktivitas TOC terkait peredaran narkotika menjadi isu yang penting dikarenakan aktivitas peredaran narkotika menimbulkan dampak seperti meningkatnya tingkat kematian global akibat narkotika dari 103.000 jiwa tahun 20124 menjadi 450.000 jiwa pada 2015.5 Serta berkontribusi terhadap peningkatan jumlah penderita HIV akibat narkotika dari 114.000 orang pada 2011 menjadi 152.000 orang pada 2015 (UNODC, 2017).

Bangladesh merupakan negara yang terletak di kawasan Asia Selatan bersama sejumlah negara lainnya seperti India, Pakistan, Afghanistan, Nepal, Bhutan, Sri Lanka serta 
berbatasan langsung dengan negara dari kawasan Asia Tenggara seperti Myanmar (BBC News, 2019). Bangladesh merupakan salah satu negara di kawasan dengan populasi terpadat setelah India dengan jumlah populasi sebesar 168,7 juta penduduk yang menjadikannya sebagai negara nomor 9 terpadat di dunia (World Population Review, 2019). Sebagaimana diketahui dalam kawasan Asia Selatan terdapat sejumlah negara yang populer dalam aktivitas peredaran narkotika seperti Afghanistan yang terkenal sebagai negara penghasil opium terbesar dunia dengan kontribusi 80\% terhadap total perdagangan opium global dan India sebagai negara produsen ketamine (Internal Drug Policy Consortium, n.d.).

Aktivitas peredaran narkotika di Asia Selatan ternyata tidak terjadi di negara yang secara tradisional berafiliasi terhadap narkotika sebagai negara produsen. Dalam peredaran substansi narkotika berjenis amphetamine (ATS) atau yang disebut 'yaba', Bangladesh merupakan negara dengan tren peningkatan peredaran substansi narkotika ATS paling konsisten dan signifikan di kawasan Asia Selatan mengacu pada laporan UNODC berjudul Regional Trends : South Asia 2013 yang menunjukkan tren peredaran yaba / ATS berdasarkan data seizures (penyitaan barang substansi) dibandingkan dengan sejumlah negara lainnya seperti India, Nepal, dan Sri Lanka sebagaimana yang dapat dilihat dalam Gambar 1(UNODC, 2013). Melalui grafis tren seizures tersebut diketahui yaba / ATS di Bangladesh menunjukkan tren peningkatan yang signifikan dan konsisten daripada negara kawasan Asia Selatan lainnya seperti India, Nepal, dan Sri Lanka yang fluktuatif meskipun data seizures di Nepal dan Sri Lanka cukup minimal sehingga tidak dapat diidentifikasi setiap tahunnya.

Peningkatan peredaran narkotika jenis yaba / ATS di Bangladesh tahun 2015-2017 terlepas dari keberadaan legal hukum Narcotic Acts 1990 yang melarang segala aktivitas ilegal berkaitan dengan narkotika telah dikategorikan ke dalam aktivitas kejahatan transnasional (TOC) terkait peredaran narkotika merujuk laporan otoritas DNC Bangladesh melalui Annual Report (DNC, 2015) maupun otoritas kepolisian melalui Strategic Plan (Bangladesh Police, n.d.). Aktivitas ini ditengarai berasal dari aktivitas pihak pengedar narkotika di wilayah negara perbatasan seperti Myanmar sehingga penulis ingin berusaha melihat faktor-faktor yang memengaruhi meningkatnya peredaran narkotika di Bangladesh yang salah satunya diduga berasal dari pihak- pihak pengedar di wilayah perbatasan seperti dengan Myanmar di mana hal ini selanjutnya menjadi basis kajian penelitian bagi penulis dalam konteks TOC yang menurut penulis menarik untuk dilaksanakan penelitian lebih lanjut. Tujuan penelitian ini adalah untuk menjelaskan faktor yang memengaruhi terjadinya peningkatan peredaran narkotika jenis yaba / ATS di Bangladesh tahun 2015-2017.

\section{KERANGKA PEMIKIRAN}

\section{Kejahatan Transnasional (Transnational Organized Crime)}

Sebagaimana merujuk kepada definisi yang dipaparkan UNODC kejahatan transnasional atau Transnational Organized Crime (TOC) merupakan bentuk aktivitas kriminal yang memiliki karakteristik seperti : dilaksanakan oleh 3 orang atau lebih secara terorganisir dalam waktu relatif lama, bertujuan mendapatkan keuntungan finansial secara langsung maupun tidak langsung, dilaksanakan di lebih dari satu negara, dilaksanakan di suatu negara namun dikendalikan dari negara lain, sampai dengan dilaksanakan di suatu negara namun menimbulkan dampak terhadap negara lain (UNODC, n.d.). Aktivitas yang dikategorikan ke dalam TOC merujuk pada laporan yang dikeluarkan oleh United Nations Congress and the Prevention of Crime and the Treatment of Offenders ke-9 di Kairo pada tahun 1995 (UNODC, 1995). 


\section{Teori Model of Anticipating Transnational Organized Crime (TOC) Phil Williams dan Roy Goodson}

Dalam penelitian ini penulis menggunakan teori Model of Anticipating Transnational Organized Crime (TOC) tulisan Phil Williams dan Roy Goodson yang bertujuan mengidentifikasi dan menjelaskan kondisi penyebab berkembangnya aktivitas TOC melalui variabel model of condition yang berisi indikator konteks politik, ekonomi, dan sosial budaya serta melalui kondisi penyebab sekaligus operasi aktivitas TOC melalui variabel model of operation yang berisi indikator konteks strategis dan bybrid untuk selanjutnya dilihat indikator penyebab apakah yang paling dominan (Williams \& Goodson, 2002).

\section{Variabel Model of Condition}

Variabel Model of Condition memberikan penjelasan mengenai kondisi yang menjadi suatu penyebab aktivitas TOC dapat terjadi di suatu negara diterangkan melalui sejumlah indikator meliputi political model, economic model dan social model yang mana dalam masingmasing indikator tersebut terdapat sejumlah parameter beserta sebuah preposisi (Williams \& Goodson, 2002).

\section{Variabel Model of Operation}

Variabel model of operation menjelaskan kondisi penyebab terjadinya aktivitas TOC sekaligus cara kerja / operasi dari aktivitas TOC tersebut melalui indikator strategic model, bybrid model (transnational) dan bybrid model (transshipment) (Williams \& Goodson, 2002). Jenis penelitian dalam penulisan ini adalah penelitian eksplanatif yang menjelaskan faktor-faktor yang memengaruhi peningkatan aktivitas peredaran yaba / ATS di Bangladesh tahun 20152017. Penelitian eksplanatif merupakan jenis penelitian berkenaan dengan pertanyaan penelitian terkait keberadaan variabel sebab-akibat (Sugiyono, 2011). Dengan ruang lingkup berfokus kepada faktor yang memengaruhi peningkatan aktivitas peredaran yaba / ATS di Bangladesh tahun 2015- 2017 Rentang tahun 2015-2017 dipilih penulis oleh karena tahun 2015 merupakan tahun di mana data mengenai peredaran yaba / ATS di Bangladesh meningkat paling signifikan daripada beberapa tahun sebelumnya yakni sebesar $211,2 \%$ yang menarik mengacu kondisi tersebut yang menjadikan yaba sebagai isu narkotika teraktual dan paling konsisten di Bangladesh meski terdapat Drug Narcotic Act 1990 yang melarang segala jenis aktivitas terkait narkotika. Selanjutnya tahun 2017 dipilih sebagai tahun penutup penelitian dikarenakan belum adanya publikasi data terbaru mengenai peredaran yaba di Bangladesh pasca 2017.

Tingkat analisa penulis dalam penelitian ini berfokus kepada state (negara) yakni secara spesifik mengenai faktor-faktor yang memengaruhi peningkatan peredaran yaba / ATS di Bangladesh tahun 2015-2017. Penulis menggunakan data sekunder dengan teknik pengumpulan studi literatur/pustaka seperti buku, jurnal, media cetak maupun elektronik, dan laman institusi formal. Teknik analisis data yang penulis gunakan adalah analisis data bersifat kualitatif. . Analisis yang diterapkan penulis dalam penelitian ini bersifat uji keabsahan data yang terdiri atas uji kredibilitas data (validitas internal), uji transferability (validitas eksternal), uji dependability (uji reliabilitas) serta uji confirmability (uji obyektivitas) dan bersifat reduksionis yakni berupa pemilahan dan pengerucutan hal penting dari data yang telah dikumpulkan oleh penulis untuk selanjutnya dihasilkan suatu kesimpulan di akhir penelitian 
(Sugiyono, 2011). Penulis juga menggunakan bantuan tabel dan grafis dalam penyajian data temuan penelitian

\section{HASIL DAN PEMBAHASAN}

Kawasan Asia Selatan dikenal sebagai kawasan bertempatnya negara dengan rekam jejak peredaran narkotika sebagaimana laporan World Drug Report 2006 yang mencatat Afghanistan sebagai negara dengan produksi opium dan heroin terbesar di dunia sejak 1990an (UNODC, 2006) dengan 80\% kontribusi peredaran opium global (Internal Drug Policy Consortium, n.d.). Selanjutnya India dikenal sebagai penghasil ketamine yang masif berdasarkan laporan UNODC Patterns and Trends of ATS and Another Drugs 2011 (UNODC, 2011). Sedangkan berdasarkan laporan UNODC Global Smart Programme Regional Trends 2013 dalam beberapa tahun terakhir sejumlah negara lain seperti Bangladesh mulai terindikasi masuk ke dalam fenomena ATS (UNODC, 2013). Bangladesh merupakan negara yang tidak memiliki reputasi narkotika masif seperti Afghanistan dan India. Akan tetapi Bangladesh cukup familier dengan peredaran narkotika seperti ganja, heroin, sampai buprenorphine (DNC, 2015). Dalam beberapa tahun terakhir Bangladesh dikatakan mengalami indikasi pergeseran tren substansi narkotika di wilayah domestik dan sekitarnya, yang mulai didominasi jenis ATS.

Narkotika jenis ATS atau "yaba" (dari bahasa Thailand yang berarti crayy pills) (DNC, 2015) adalah narkotika jenis stimulan yang digunakan tentara Nazi pada Perang Dunia II (Ahmed \& Liton, 2018) dengan ukuran sebesar lubang sedotan dan memiliki beragam rasa dan warna mulai merah sampai hijau dengan simbol huruf WY atau R. Yaba / ATS memiliki efek yang lebih lama terhadap pusat saraf daripada narkotika lain seperti kokain yang menimbulkan dampak berbahaya berupa halusinasi sampai kerusakan pembuluh darah pada otak. (Islam, Tabassum, Shafiuzzaman, Umar, \& Khanam, 2013). Yaba awalnya tidak beredar secara tradisional di Bangladesh yang lebih familier dengan narkotika seperti ganja sampai buprenorphine. Kemunculan yaba diketahui sejak tahun 2007, tetapi dalam periode tersebut peredaran yaba masih minim dan belum signifikan (Roy, 2018). Yaba baru menunjukkan grafik angka yang melesat masif pada tahun 2015- 2017 di mana peningkatan peredaran yaba dari tahun sebelumnya melebihi persentase $100 \%$ yakni $211,22 \%$. Grafis peredaran yaba yang diketahui dari jumlah seizures bergerak konsisten setiap tahun daripada heroin dan ganja yang fluktuatif. Indikasi peningkatan peredaran yaba / ATS tahun 20152017 diperkuat oleh keterangan sejumlah media massa yang memberitakan signifikansi peredaran yaba / ATS sebagai isu aktual. Di antaranya Asia News Network yang menjelaskan berhasil diamankannya 5 juta pil yaba / ATS pada tahun 2015-2016 (Asia News Network, 2016) dan Business Standard yang memaparkan berhasil diamankannya 15 juta pil yaba / ATS pada 2017 (Business Standard, 2018).

Hal tersebut turut diperkuat oleh pernyataan dari pihak DNC Bangladesh melalui laporan Annual Drug Report 2015 yang menegaskan yaba / ATS sebagai jenis narkotika yang menjadi isu aktual Bangladesh dibandingkan heroin dan ganja(DNC, 2015). Di samping peningkatan dari tahun sebelumnya yang lebih besar, angka kenaikan peredaran yaba / ATS juga lebih stabil. Apabila merujuk pada laporan DNC diketahui angka peningkatan peredaran yaba / ATS di Bangladesh tahun 2015 merupakan yang tertinggi dari tahun-tahun sebelumnya dari (6.512.869) pil menjadi sebesar (20.269.045) atau sebesar 211,2\% yang merupakan persentase tertinggi selama 5 tahun terakhir sebagaimana dapat dilihat dalam Tabel 2:

Tabel 2. Tabel Kenaikan Jumlah Seizures Narkotika jenis Yaba / ATS (2011-2017)

\begin{tabular}{|c|c|c|}
\hline Tahun & Jumlah Yaba & Persen Kenaikan \\
\hline 2011 & 1.360 .186 & $67,36 \%$ \\
\hline
\end{tabular}




\begin{tabular}{|l|l|l|}
\hline 2012 & 1.951 .392 & $43,47 \%$ \\
\hline 2013 & 2.821 .528 & $44,59 \%$ \\
\hline 2014 & 6.512 .869 & $130,83 \%$ \\
\hline 2015 & 20.269 .045 & $211,22 \%$ \\
\hline 2016 & 29.450 .178 & $45,30 \%$ \\
\hline 2017 & 40.079 .443 & $36,09 \%$ \\
\hline
\end{tabular}

Sumber: DNC Annual Drug Report 2015- 2017 (DNC, 2015)(DNC, 2017)

Kenaikan persentase peredaran yaba / ATS pada tahun 2015 bersamaan dengan naiknya jumlah kasus peredaran yaba / ATS. Pada 2015-2017 kasus terus meningkat dan memperkuat gambaran peredaran yaba / ATS di Bangladesh tahun 2015-2017 sebagaimana dapat diamati melalui:

Tabel 3. Jumlah Kasus (Cases) Peredaran Narkotika Jenis Yaba / ATS di Bangladesh Tahun 2015-2017

\begin{tabular}{|c|c|}
\hline TAHUN & Cases \\
\hline 2015 & 1074 \\
\hline 2016 & 2130 \\
\hline 2017 & 3053 \\
\hline
\end{tabular}

Sumber: DNC Annual Drug Report 2015- 2017 (DNC, 2015)(DNC, 2017)

Yaba / ATS besar dimungkinkan diproduksi di Myanmar merujuk penjelasan DNC Annual Report apabila substansi ini banyak diproduksi di negara bagian Shan. Sedangkan aktor peredaran yaba / ATS ditengarai merupakan sejumlah kelompok pemberontak di Myanmar merujuk laporan media massa Bangladesh Dhaka Tribune (Mahmud, 2018) dan media massa Myanmar The Irrawady (Myat, 2018) yang mendirikan 37 titik pabrik yaba di negara bagian Shan. Kelompok pemberontak tersebut meliputi United Wa State Army (Mahmud, 2018) sampai dengan Arakan Army (The Stateless Rohingya, 2015).

\section{Gambar 3. Titik Pabrik Yaba / ATS Milik Kelompok Pemberontak di Negara Bagian Shan, Myanmar}

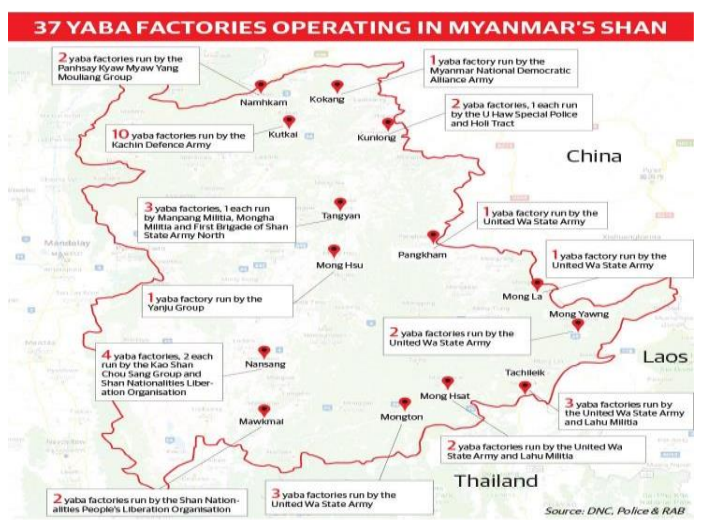

Sumber: Diakses oleh penulis dari Dhaka Tribune (Mahmud, 2018).

Keterlibatan sejumlah kelompok pemberontak Myanmar dalam aktivitas peredaran yaba / ATS dari Myanmar ke Bangladesh diperkuat oleh laporan lembaga kemanusiaan seperti The Stateless Rohingya atau Advisory Commission on Rakbine State yang sama-sama menyatakan keterlibatan Arakan Army dalam aktivitas peredaran yaba / ATS (Advisory Commision on Rakhine State, n.d.). Keterangan lainnya dijelaskan media massa Myanmar The Irrawaddy mengenai penangkapan pengedar yaba / ATS yaitu U Wai Tha Tun sebagai 
rekan salah satu pemimpin Arakan Army, Mayor Jenderal Aung Myat Kyaw dengan 300.000 pil yaba (The Irrawaddy, 2019). Di samping itu pada Februari 2018 Pemerintah Myanmar berhasil menangkap 4 pelaku peredaran yaba / ATS dari Arakan Army yang memasok sebesar 4,4 juta pil yaba / ATS sepanjang Desember 2016 - November 2017 (The Irrawaddy, 2019). Mayor Jenderal Aung Myat Kyaw di pengadilan mengakui keterlibatan Arakan Army dalam aktivitas peredaran yaba / ATS untuk membiayai aktivitas kelompok tersebut seperti membeli senjata (Myanmar News Agency, 2016).

\section{Gambar 4. Grafis Keterlibatan Kelompok Pemberontak Arakan Army dalam Peredaran Yaba / ATS dari Myanmar ke Bangladesh}

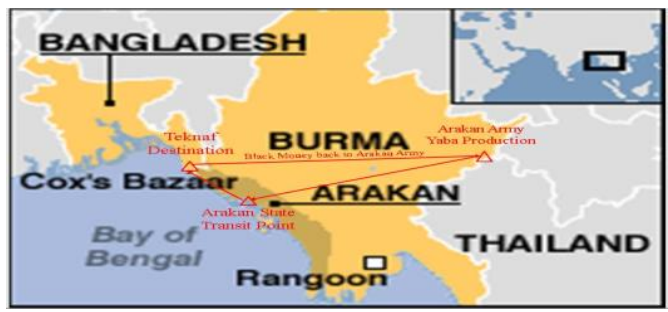

Sumber: Bangladesh a Breeding Ground for Rakhine Terrorists (The Stateless Rohingya, 2015)

Gambaran jalur peredaran yaba / ATS merujuk pada media Asia Times bermula di Shan State menuju jalur Shan-Yangon-Sittwe atau Buthidaung-pegunungan Mayu atau Sungai Naf di Bangladesh (Mathieson, 2017) selanjutnya masuk ke kota perbatasan seperti Chittagong dan sekitarnya (Kaladan Press, 2015). Hal ini didukung posisi kelompok pemberontak seperti United Wa State Army di Shan State yang memiliki banyak titik pabrik yaba di Myanmar dan merupakan sekutu Arakan Army yang turut andil dalam peredaran yaba / ATS ke Bangladesh (The Irrawaddy, 2019). Keterkaitan Wa State Army dalam produksi yaba / ATS dijelaskan melalui simbol huruf WY pada tablet yaba (France 24, 2017).

\section{Variabel Model of ConditionsPolitical Model}

Weak states

Parameter weak states ditandai dengan crime rate tinggi serta law enforcement rendah (Williams \& Goodson, 2002). Berdasarkan temuan penelitian Bangladesh memenuhi kriteria weak state. Hal ini dibuktikan dengan data mengenai tingginya crime rate Bangladesh sebagaimana dapat dilihat pada Tabel 4 yang diperoleh dari laman resmi Bangladesh Police. Pada tabel tersebut diketahui angka crime rate di Bangladesh berada dalam angka cukup tinggi yakni mencapai 179.880 kasus pada tahun 2015 (Bangladesh Police, 2015), 181.168 kasus pada tahun 2016 (Bangladesh Police, 2016), serta 213.529 kasus pada tahun 2017. Angka kasus kriminalitas tersebut diketahui terus meningkat meliputi berbagai aktivitas kriminal seperti perampokan bersenjata sampai dengan penyelundupan (Bangladesh Police, 2017).

Tabel 4. Data Kasus Kriminalitas di Bangladesh Tahun 2015-2017

\begin{tabular}{|c|c|}
\hline TAHUN & Crime Cases \\
\hline 2015 & 179.880 \\
\hline 2016 & 181.168 \\
\hline 2017 & 213.529 \\
\hline
\end{tabular}

Sumber: Bangladesh Police Crime Statistics 2017 (Bangladesh Police, 2017).

Indikasi crime rate tinggi di Bangladesh diperkuat oleh data tingkat bomicide (pembunuhan dengan kekerasan) tahun 2015-2017 merujuk pada publikasi World Bank (World Bank, n.d.-c). Melalui tingkat homicide yang digunakan sejumlah literatur sebagai 
indikasi mengukur crime rate (UNODC, 2016). diketahui angka rata-rata homicide di Bangladesh adalah 2,30. Angka ini berada di bawah rata-rata negara kawasan Asia Selatan yang berada pada angka 2,59 yang bila diurutkan tetap menempatkan Bangladesh di atas India, Bhutan, Maladewa dan Nepal (data ditulis 0 karena sejauh berlangsungnya penelitian belum dapat diketahui) meski di bawah Afghanistan, Pakistan dan Sri Lanka.

Tabel 5. Homicide Rate di Sejumlah Negara Kawasan Asia Selatan Tahun 2015-

\begin{tabular}{|c|c|c|c|c|c|c|c|c|} 
TAHUN & AFGHAN & BANGLA & BHUTAN & INDIA & MALDIVE & NEPAL & PAKISTAN & SRILANK \\
\hline 2015 & 10 & 2,5 & 1,5 & 3,4 & 0 & 0 & 5 & 2,4 \\
\hline 2016 & 6,6 & 2,2 & 1,1 & 3,2 & 0 & 0 & 4,4 & 2,5 \\
\hline 2017 & 7,1 & 2,2 & 1,6 & 0 & 0 & 0 & 4,2 & 2,3 \\
\hline AVERAGE & 7,90 & 2,30 & 1,40 & 2,20 & 0,00 & 0,00 & 4,53 & 2,40 \\
\hline AV TOTAL & 2,59 & & & & & & &
\end{tabular}

2017

Sumber: International Classification of Crime for Statistical Purposes (UNODC, 2016)

Indikasi selanjutnya diperkuat dengan pernyataan Kedutaan Besar (Kedubes) Amerika Serikat (AS) di Bangladesh tahun 2015-2017 yang mengategorikan crime rate Bangladesh dalam level bigh (OSAC, 2017).

"The US Department of State has assessed Dhaka as being a high-treat location for crime directed at or affecting Official US Government interests. Crime rating: High. Crime threats: Financial scams, vehicle thefts, and petty drug crimes comprise the majority of criminal activity in Dhakea and other major cities in Bangladesh. Homicides, sexual assaults, robberies, and residential break-ins occurs with regular frequency but do not exceed average levels of major cities in the US" (OSAC, 2017).

Selanjutnya indikasi rendahnya law enforcement rate di Bangladesh pada tahun 20152017 dibuktikan oleh Tabel 6 yang berisikan indeks criminal justice dari laporan World Justice Project.

Tabel 6 . Indeks Criminal Justice Bangladesh Tahun 2015-2017

\begin{tabular}{|c|c|c|c|}
\hline NEGARA & 2015 & 2016 & \multicolumn{1}{|c|}{2017} \\
\hline Bangladesh & $0,33(88)$ & $0,33(97)$ & $0,34(96)$ \\
\hline Afghanistan & $0,24(100)$ & $0,28(109)$ & $0,28(108)$ \\
\hline India & $0,47(44)$ & $0,41(71)$ & $0,42(66)$ \\
\hline Pakistan & $0,31(94)$ & $0,38(81)$ & $0,38(81)$ \\
\hline Sri Lanka & $0,45(46)$ & $0,49(52)$ & $0,48(53)$ \\
\hline Nepal & $0,42(56)$ & $0,44(60)$ & $0,43(63)$ \\
\hline
\end{tabular}

Sumber: World Justice Report 2015-2017 (World Justice Project, 2018)

Melalui Tabel 6 tersebut diketahui law enforcement rate di Bangladesh tahun 2015-2017 yang ditunjukkan dalam skala nilai 0-1 (World Justice Project, 2018). Pada tahun 2015-2017 law enforcement rate Bangladesh memperoleh nilai 0,33 pada tahun 2015,154 0,33 (2016),(World Justice Project, 2016) dan 0,34 (2017)(World Justice Project, 2018) yang membuatnya menduduki peringkat kedua terendah dibandingkan negara Asia Selatan lainnya seperti India, Pakistan, Sri Lanka dan Nepal yang bila merujuk skala nilai 0-1 tersebut maka terindikasi rendah.

Penulis selanjutnya melakukan verifikasi temuan penelitian terhadap preposisi aktivitas kelompok TOC cenderung timbul dan berkembang di negara dengan kategori weak states (Williams \& Goodson, 2002). Sehingga melalui verifikasi ini preposisi aktivitas TOC cenderung berkembang di negara yang dikategorikan sebagai weak-state adalah benar. Londisi Bangladesh sebagai weak state dengan crime rate tinggi dan law enforcement rendah memengaruhi peningkatan peredaran narkotika jenis yaba / ATS di Bangladesh tahun 2015-2017 seiring 
kondisi rendahnya aspek seperti law enforcement memengaruhi peningkatan aktivitas TOC yang sebaliknya bergerak leluasa.

Strong state to weak

Parameter strong state to weak ditandai oleh kriteria keberadaan kondisi transisi rezim kuat menuju rezim lebih lemah yang memengaruhi berkembangnya aktivitas TOC (Williams \& Goodson, 2002). Melalui temuan penelitian Bangladesh diketahui tidak memiliki keberadaan transisi rezim kuat ke lemah sehingga kriteria parameter strong state to weak belum dapat dipenuhi. Hal ini dibuktikan dengan data publikasi laporan Democracy Index 2015-2017 mengenai indeks demokrasi berbagai negara di dunia dengan melihat faktor seperti proses elektorat sampai kebebasan sipil. Bangladesh dikategorikan sebagai negara bybrid regime dengan perolehan nilai sebesar 5,73 pada tahun 2015,160 5,73 (2016),(The Economist, 2017) dan 5,43 (2017) (The Economist, 2018). Hybrid regime menjelaskan kondisi demokrasi tidak cukup baik dengan proses elektorat janggal sampai dengan kekerasan terhadap media dan berada setingkat di atas authoritarianism sebagai kondisi tidak berjalannya demokrasi (The Economist, 2018). Sehingga kondisi Bangladesh dengan bybrid regime yang undemocratic serta tingkat law enforcement rendah yang membuatnya bukan merupakan strong state to weak tidak memengaruhi peningkatan peredaran tren narkotika jenis yaba di Bangladesh tahun 20152017

\section{Weak states with Ethnic Conflicts / Terrorism}

Parameter weak states with ethnic conflicts / terrorism ditandai dengan kriteria keberadaan konflik etnis (ethnic conflicts) dan terorisme (terrorism) yang memengaruhi timbulnya aktivitas TOC (Williams \& Goodson, 2002). Dalam temuan penelitian diketahui Bangladesh memiliki keberadaan kasus konflik etnis dan terorisme sehingga memenuhi kriteria weak state with ethnic conflicts / terrorism. Hal ini dapat dibuktikan melalui data kasus konflik etnis dan terorisme di Bangladesh tahun 2015-2017 yang dapat dilihat dalam Tabel 7. Melalui tabel tersebut diketahui jumlah keberadaan kasus konflik etnis dan terorisme di Bangladesh. Kasus konflik etnis dan terorisme tersebut termasuk kasus penyerangan komunitas Muslim Shia (2015),(Odhikar, 2015) penyerangan puluhan warga asing di Dhaka oleh kelompok AQIS (Al-Qaida in The Indian Subcontinent) pada 2016 (Odhikar, 2016a) dan penyerangan terhadap komunitas Hindu, tokoh komunitas Ahmadiyah, maupun tokoh komunitas Kristen pada 2017 (Odhikar, 2017).

Tabel 7. Jumlah Kasus Konflik Etnis dan Terorisme di Bangladesh Tahun 20152017

\begin{tabular}{|c|c|}
\hline TAHUN & Ethnic Conflict / Terrorism Cases \\
\hline 2015 & 24 \\
\hline 2016 & 22 \\
\hline 2017 & 12 \\
\hline
\end{tabular}

Sumber: Odbikar Bangladesh Human Rights Report 2015-2017 \& Refworld (Odhikar, 2017)(US Department of State, 2018)

Selanjutnya penulis melakukan verifikasi temuan penelitian penulis terhadap preposisi aktivitas TOC cenderung berkembang di negara weak state dengan keberadaan konflik etnis atau terorisme(Williams \& Goodson, 2002). Melalui verifikasi tersebut preposisi aktivitas TOC cenderung berkembang di negara dengan keberadaan konflik etnis / terorisme adalah benar. Sehingga kondisi Bangladesh sebagai weak state with ethnic conflict / terrorism 
dengan keberadaan konflik etnis dan terorisme memengaruhi peningkatan tren peredaran narkotika jenis yaba / di Bangladesh tahun 2015-2017 seiring keberadaan konflik etnis dan terorisme di Bangladesh menjadi salah satu indikator lemahnya keamanan domestik negara yang membuat aktivitas TOC bergerak leluasa.

\section{High Legitimate States}

Parameter high legitimate states ditandai dengan democratic condition serta law enforcement rate yang cukup tinggi (Williams \& Goodson, 2002). Berdasarkan temuan penelitian Bangladesh diketahui merupakan negara yang undemocratic serta memiliki law enforcement rate rendah sehingga tidak memenuhi kriteria high legitimate states. Hal ini dibuktikan melalui data serupa yang digunakan dalam melihat parameter strong state to weak seperti pada penjelasan sebelumnya yaitu data indeks demokrasi pada halaman 68. Melalui tabel tersebut diketahui Bangladesh mendapatkan nilai sebesar 5,73 (2015), 5,73 (2016), dan 5,43 (2017) yang membuatnya mendapatkan predikat bybrid regime yang tidak memenuhi democratic condition karena hanya setingkat di atas authoritarianism (Williams \& Goodson, 2002).

Selanjutnya indikasi law enforcement rate di Bangladesh yang rendah dibuktikan melalui law enforcement rate Bangladesh melalui indeks criminal justice Bangladesh tahun 2015-2017 sebagaimana yang sebelumnya dapat dilihat dalam Tabel 6 pada parameter strong state to weak. Melalui tabel tersebut diketahui Bangladesh memperoleh nilai sebesar 0,33 (2015), 0,33(2016), dan 0,34(2017) yang membuatnya menempati peringkat terendah kedua di negara kawasan Asia Selatan setelah Afghanistan sehingga terindikasi rendah. Sehingga kondisi Bangladesh dengan bybrid regime yang undemocratic dan law enforcement rendah membuatnya bukan sebagai high legitimate states dan tidak memengaruhi peningkatan peredaran narkotika jenis yaba / ATS tahun 2015-2017.

\section{Economic Model}

Market Model

Parameter market model ditandai oleh kriteria berupa permintaan pasar barang ilegal yang besar terkait aktivitas TOC (Williams \& Goodson, 2002). Melalui temuan penelitian diketahui Bangladesh memiliki pasar permintaan yaba / ATS yang besar tahun 2015-2017 sehingga memenuhi kriteria market model. Hal ini diindikasikan melalui data yang diolah penulis dari laporan DNC Annual Report tahun 2015-2017 sebagaimana dapat dilihat pada Tabel 8. Tabel ini menggambarkan jumlah permintaan pasar yaba / ATS yang dihitung dari jumlah yaba yang diamankan (seizures) dari berbagai provinsi di Bangladesh mulai dari Dhaka sampai dengan Sylhet (DNC, 2017).

Tabel 8. Jumlah Narkotika Jenis Yaba / ATS yang Berhasil Diamankan di Seluruh Provinsi Bangladesh 2015-2017

\begin{tabular}{|c|c|c|c|c|c|c|}
\hline TAHUN & Case 15' & Case 16' & Case 17' & 2015 & 2016 & 2017 \\
\hline Dhaka Div & 554 & 1641 & 2310 & 246909 & 527428 & 630991 \\
\hline Mymensingh Div & 58 & 64 & 38 & 8257 & 2612 & 5699 \\
\hline Chittagong Div & 366 & 1096 & 1809 & 3097374 & 1715164 & 1225414 \\
\hline Rajshahi Div & 126 & 648 & 677 & 29109 & 61151 & 75776 \\
\hline Rangpur Div & 26 & 74 & 127 & 2247 & 5799 & 5468 \\
\hline Khulna Div & 120 & 468 & 617 & 7799 & 55486 & 44489 \\
\hline
\end{tabular}




\begin{tabular}{|c|c|c|c|c|c|c|}
\hline Barisal Div & 22 & 14 & 102 & 1662 & 112 & 4926 \\
\hline Sylhet Div & 32 & 158 & 218 & 600 & 6293 & 21080 \\
\hline
\end{tabular}

Sumber: Bangladesh Department of Narcotic Control (DNC, 2017).

Jumlah narkotika jenis yaba / ATS yang berhasil diamankan (seizures) di suatu wilayah negara diketahui dapat mengindikasikan keberadaan permintaan pasar di wilayah tersebut sebagaimana yang dibuktikan riset narkotika Seefar (Seefar, n.d.). Berdasarkan Tabel 8 tersebut diketahui Bangladesh memiliki permintaan pasar yang besar terhadap narkotika jenis yaba / ATS di sejumlah provinsi seperti Dhaka, Chittagong, Rajshahi, Khulna, dan Sylhet pada tahun 2015-2017 yang mencapai angka puluhan ribu sampai jutaan kemasan (pcs).

\section{Enterprise Model}

Parameter enterprise model ditandai dengan kriteria keberadaan permintaan pasar beserta profit besar terkait aktivitas TOC (Williams \& Goodson, 2002). Berdasarkan temuan penelitian diketahui Bangladesh memiliki permintaan pasar disertai dengan profit besar terkait yaba / ATS. Hal ini dapat dibuktikan melalui estimasi nilai profit dari data mengenai permintaan pasar yaba / ATS di Bangladesh tahun 2015-2017 yang telah diketahui pada penjelasan sebelumnya melalui Tabel 8. Dalam mengalkulasi besar profit dalam pasar permintaan yaba / ATS penulis mengumpulkan data harga beli serta harga jual untuk satuan pil yaba / ATS melalui referensi media lokal seperti Daily Star yang mengungkap besaran harga beli satuan yaba / ATS dari pabrik yang berada di Myanmar sebesar 4-5 Taka (Tk) untuk pil jenis WY serta sebesar 10-12 Tk untuk pil jenis R7. Sedangkan Daily Star melansir harga beli dari penjual yaba / ATS lokal Bangladesh sebesar 65 Tk.(Khan, 2019) Untuk harga jual setiap jenis pil yaba / ATS penulis mendapatkan referensi dari media seperti Dhaka Tribune di mana diketahui harga jual pil yaba / ATS terendah dimiliki jenis "Champa" sebesar 70-120 Tk sampai 220-330 Tk (Khan, 2016). Kemudian jenis lainnya seperti "R" sebesar 500 Tk serta 700-900 Tk.(Khan, 2016) Jenis selanjutnya sekaligus termahal adalah "Controller" dengan harga sebesar 1500-2000 Tk. (Khan, 2016).

Selanjutnya penulis melakukan penghitungan rata-rata sehingga diperoleh harga beli sebesar 19 Tk dan harga jual sebesar 704 Tk untuk dikalikan dengan data permintaan pasar dari setiap provinsi di Bangladesh sebagaimana dalam parameter market model sehingga diperoleh profit dari pasar permintaan yaba / ATS di Bangladesh tahun 2015-2017. Hasil kalkulasi profit yang diperoleh selanjutnya dikonversi ke dalam satuan U\$D agar lebih mudah dipahami dengan menyesuaikan kurs mata uang Taka ( Tk) terhadap U\$D pada setiap tahun. Melalui Tabel 9 diketahui sejumlah provinsi di wilayah perbatasan seperti Chittagong dan Dhaka mencatat rata-rata estimasi nilai profit tertinggi dengan profit sebesar U\$D 17,6 juta serta U\$D 4,9 juta sedangkan profit terendah diraih Barisal dengan U\$D 19 ribu. Rata-rata profit dari seluruh provinsi Bangladesh mengacu tabel tersebut adalah U\$D 2, 85 juta. Sehingga dapat diketahui profit pasar permintaan yaba / ATS di Bangladesh tahun 20152017 relatif besar, mengacu kepada perolehan profit tersebut yang lebih besar bila dibandingkan rata-rata GDP per kapita masyarakat Bangladesh tahun 2015-2017 yang diketahui sebesar U\$ 1.404.689 juta (World Bank, n.d.-a). Selain itu nilai profit terbesar yang berada di wilayah provinsi perbatasan seperti Chittagong dan Dhaka yang berbatasan dengan Myanmar semakin memperkuat keberadaan peredaran narkotika jenis yaba / ATS berasal dari perbatasan Bangladesh- Myanmar. 
Tabel 9. Estimasi Nilai Permintaan Pasar dan Profit Narkotika Jenis Yaba / ATS di Bangladesh 2015-2017

\begin{tabular}{|c|r|}
\hline \multicolumn{2}{|c|}{ Harga Beli (Tk) } \\
\hline WY & 4 \\
\hline WY & 5 \\
\hline R7 & 10 \\
\hline R7 & 12 \\
\hline All & 65 \\
\hline Rata-rata & 19 \\
\hline
\end{tabular}

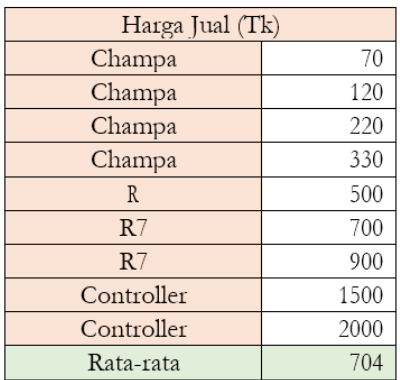

$1 \mathrm{Tk}=1 / 77,86 \mathrm{USD} 1 \mathrm{Tk}=1 / 77,53 \mathrm{USD} 1 \mathrm{Tk}=1 /$ 79,3 USD

\begin{tabular}{|c|c|}
\hline TAHUN & Rata-rata Profit 2015-2017 \\
\hline Chittagong Div & $\$ 17.663 .136$ \\
\hline Dhaka Div & $\$ 4.094 .266$ \\
\hline Rajshahi Div & $\$ 483.648$ \\
\hline Khulna Div & $\$ 314.383$ \\
\hline Rangpur Div & $\$ 118.238$ \\
\hline Sylhet Div & $\$ 80.990$ \\
\hline Mymensingh Div & $\$ 48.317$ \\
\hline Barisal Div & $\$ 19.388$ \\
\hline Rata-rata Total & $\$ 2.852 .796$ \\
\hline
\end{tabular}

Sumber: Data diolah penulis dari DNC Annual Drug Report 2015-2017, Dhaka Tribune, Daily Star. (DNC, 2017) (Khan, 2016)(Mehtab \& Rahman, 2018)(Khan \& Jinnat, 2019)(Khan, 2019).

Selanjutnya penulis memverifikasi temuan penulis dengan preposisi aktivitas TOC cenderung melakukan diversifikasi terhadap pasar serta produk illegal sebagai bagian dari aktivitasnya (Mehtab \& Rahman, 2018). Melalui verifikasi aktivitas peredaran yaba / ATS di Bangladesh tahun 2015-2017 diketahui mengalami diversifikasi pasar mengacu pada permintaan pasar serta nilai profit besar di sejumlah provinsi seperti Mymensingh, Rajshahi, Barisal, dan Sylhet yang tidak lagi berkutat pada provinsi terdekat dengan perbatasan yang ditengarai menjadi titik masuk yaba / ATS dari Myanmar seperti Dhaka atau Chittagong dan membuktikan preposisi aktivitas TOC cenderung melakukan diversifikasi pasar serta produk ilegal adalah benar. Sehingga kondisi Bangladesh dengan profit besar dari permintaan pasar yaba / ATS mengacu jumlah yang melebihi rata-rata GDP per kapita sebagai enterprise model memengaruhi peningkatan peredaran yaba / ATS di Bangladesh tahun 2015-2017.

\section{Social Model}

Parameter cultural model ditandai oleh kriteria keberadaan ikatan kekeluargaan atau patron-klien dalam aktivitas TOC(Williams \& Goodson, 2002). Melalui temuan penelitian yang diperoleh penulis maka aktivitas peredaran narkotika jenis yaba / ATS di Bangladesh tahun 2015-2017 diketahui memiliki ikatan kekeluargaan di dalamnya sehingga memenuhi kriteria cultural model. Hal ini dapat dibuktikan dari seorang godfather yaba / ATS bernama Saiful Karim atau SK yang ditembak mati otoritas Bangladesh dalam kontak senjata tahun 
2018 (The Independent, 2019) Saiful Karim diketahui terlibat dalam bisnis peredaran yaba / ATS sejak tahun 2001 melalui bisnis impor kayu dari Myanmar ke Bangladesh dengan nama SK International yang didirikan melalui relasi dengan godfather yaba / ATS paling diburu di Myanmar yaitu Moga Sibin (Azis, 2019).

\section{Ethnic Network. Model}

Parameter ethnic network ditandai dengan kriteria keberadaan ikatan / relasi seperti etnis dan diaspora terkait aktivitas TOC.(Williams \& Goodson, 2002) Melalui temuan penelitian diketahui peredaran narkotika jenis yaba / ATS di Bangladesh tahun 2015-2017 memiliki keberadaan ikatan etnis dan diaspora sehingga memenuhi kriteria ethnic network. Hal ini dibuktikan dari aktivitas peredaran yaba / ATS yang tidak hanya dilakukan masyarakat lokal Bangladesh melainkan juga masyarakat etnis Rohingya yang berasal dari Myanmar sebagaimana dapat dilihat dalam Tabel 10. Keterlibatan etnis Rohingya diketahui melalui jumlah kasus serta penangkapan. Etnis Rohingya mencatat 86 kasus dengan jumlah arrest 290 orang pada 2015, 70 kasus dengan jumlah arrest 139 orang (2016), dan 104 kasus dan jumlah arrest lebih kurang lebih 192 orang (2017) (Mahmud, 2017).

\section{Tabel 10. Jumlah Case dan Arrest Etnis Rohingya terkait Peredaran Narkotika Jenis Yaba / ATS Tahun 2015-2017}

\begin{tabular}{|c|c|c|}
\hline Cases & MEDIA (Rohingya's Yaba Cases and Arrest 2015) & Arrest \\
\hline 86 & $\begin{array}{c}\text { Dhaka Tribune: Yaba Smugglers Entering Bangladesh in Disguise of Displaced } \\
\text { Rohingyas (Dec 17) }\end{array}$ & 290 \\
\hline Cases & MEDIA (Rohingya's Yaba Cases and Arrest 2016) & Arrest \\
\hline 70 & $\begin{array}{c}\text { Dhaka Tribune: Yaba Smugglers Entering Bangladesh in Disguise of Displaced } \\
\text { Rohingyas (Dec 17) }\end{array}$ & 139 \\
\hline Cases & MEDIA (Rohingya's Yaba Cases and Arrest 2017) & Arrest \\
\hline 92 & $\begin{array}{c}\text { Dhaka Tribune: Yaba Smugglers Entering Bangladesh in Disguise of Displaced } \\
\text { Rohingyas (Dec 17) }\end{array}$ & 192 \\
\hline
\end{tabular}

Sumber: Yaba Smugglers Entering Bangladesh in Disguise of Displaced Robingyas (Mahmud, 2017).

Sebagian besar masyarakat Rohingya melakukan aktivitas diaspora ke Bangladesh oleh karena aksi represif Pemerintah Myanmar yang tidak mengakui Rohingya sebagai etnis di Myanmar (Giordana, 2017). Diaspora adalah aktivitas berpindahnya penduduk dari suatu tempat ke tempat lainnya yang jauh dari tempat asal dan melintasi batas negara karena berbagai faktor seperti kehilangan tempat tinggal sampai mencari pekerjaan (Britannica, n.d.). Tidak diakuinya Rohingya sebagai etnis mendorong sejumlah aksi Pemerintah Myanmar seperti pada bulan Agustus 2017 di mana gelombang eksodus etnis Rohingya ke Bangladesh meningkat pesat mencapai angka 380.000-720.000 (ISCG, 2018) sebagai imbas serangan balasan militer Myanmar terhadap kelompok pemberontak Rohingya Salvation Army (ARSA) (Giordana, 2017). Sebelumnya pada tahun 2016 diperkirakan sudah terdapat 500.000 etnis Rohingya di Bangladesh sebagai dampak aktivitas eksodus (Giordana, 2017).

Social Network Model

Parameter social network ditandai oleh kriteria keberadaan ikatan / relasi aktivitas TOC dengan institusi legal / formal atau elite institusi tersebut (Williams \& Goodson, 2002). Melalui temuan penelitian diketahui peredaran narkotika jenis yaba / ATS di Bangladesh tahun 2015-2017 memiliki keberadaan ikatan / relasi dengan institusi legal / formal sehingga 
memenuhi kriteria social network. Hal ini dapat dibuktikan seiring aktivitas peredaran yaba / ATS tidak hanya dilakukan oleh pihak sipil biasa. Akan tetapi juga dilakukan oleh pihak yang berasal institusi formal seperti kepolisian, pemerintahan, serta militer yang dijelaskan sebagai berikut.

\section{Kepolisian}

Keterlibatan sejumlah oknum dari institusi kepolisian Bangladesh dalam aktivitas peredaran narkotika jenis yaba / ATS di Bangladesh tahun 2015-2017 berhasil diungkap melalui keberadaan Mahfuzur Rahman selaku asisten sub-inspektur polisi dari Special Branch di Dhaka dengan barang bukti 680.000 butir pil yaba, handphone, kartu kredit, serta daftar riwayat penjualan yaba / ATS (Khan, 2015). Pengungkapan Mahfuzur Rahman sekaligus mengungkap keterlibatan beberapa oknum kepolisian lainnya seperti asisten sub- inspektur polisi dari Detective Branch di Cox's Bazar dan sub-inspektur polisi Mhd. Ashiq yang bertugas di Chittagong serta oknum polisi lainnya seperti Shahin, Kashem, dan Giash (Khan, 2015).

\section{Municipal Councillor (Dewan Kota)}

Keterlibatan seorang -anggota dewan kota di Bangladesh (CLGF, 2017) dalam aktivitas peredaran yaba / ATS di Bangladesh tahun 2015-2017 berhasil diungkap melalui nama Abdul Matin dari Kota Bogra (Huda, 2017). Abdul Matin merupakan anggota dewan kota dari partai politik Awami League di Bangladesh dan ditangkap pada 2017 atas keterlibatannya dalam aktivitas peredaran yaba / ATS di Kota Bogra, Kahalu serta beberapa desa (upazila) di sekitarnya (Huda, 2017).

\section{High Court}

Keterlibatan staf administrasi dari pengadilan tinggi Bangladesh dalam aktivitas peredaran yaba / ATS di Bangladesh tahun 2015-2017 berhasil diungkap melalui nama Mhd. Motaleb yang diungkap dari daftar riwayat penjualan yaba / ATS milik Nafizur Rahman selaku oknum polisi yang berhasil diungkap keterlibatannya dalam aktivitas peredaran yaba / ATS pada 2017 (Khan, 2015).

\section{Militer}

Nama sejumlah oknum militer diketahui terlibat dalam aktivitas peredaran narkotika jenis yaba / ATS di Bangladesh tahun 2015-2017. Oknum militer tersebut bernama Shihab Uddin dan Shafiqul Islam dengan pangkat private yang bertugas di Chittagong yang ditangkap pada bulan Desember 2017 dengan 50.000 pil yaba (Hussain, 2017). Selain itu sejumlah oknum militer Myanmar bernama Lu Shae dan Kyaw Sein Tun juga ditangkap pada Oktober 2017 di Maungdaw dekat perbatasan Bangladesh-Myanmar dengan 1,8 juta pil yaba yang menunjukkan keberadaan oknum militer dalam aktivitas peredaran narkotika jenis yaba / ATS di Bangladesh tahun 2015-2017 (Tun, 2017).

Selanjutnya penulis melakukan verifikasi temuan penelitian terhadap preposisi aktivitas TOC cenderung bekerja sama dengan institusi legal atau elite (Williams \& Goodson, 2002). Melalui verifikasi ini diketahui preposisi aktivitas TOC cenderung bekerja sama dengan institusi legal adalah benar. Preposisi ini berhasil dipenuhi sehingga kondisi keberadaan ikatan antara aktivitas peredaran yaba / ATS dengan institusi formal seperti 
oknum kepolisian sampai militer baik di Bangladesh atau Myanmar memengaruhi peningkatan peredaran narkotika jenis yaba / ATS di Bangladesh tahun 2015-2017 seiring keberadaan aktualisasi keterlibatan institusi legal dalam aktivitas peredaran yaba / ATS sebagai bentuk TOC menjadi salah satu indikator lemahnya legitimasi dan kredibilitas negara dalam menghadapi TOC dan selanjutnya membuat aktivitas TOC secara bersamaan bergerak leluasa dengan keterlibatan sejumlah oknum tersebut.

\section{Variabel Model of Operation Strategic Model}

Risk Prevention

Parameter risk prevention ditandai dengan kriteria keberadaan safe haven terkait aktivitas TOC (Williams \& Goodson, 2002). Dari temuan penelitian maka diketahui apabila aktivitas peredaran narkotika jenis yaba / ATS di Bangladesh tahun 2015-2017 memiliki keberadaan sejumlah safe haven sehingga memenuhi kriteria risk prevention. Hal ini dapat dibuktikan melalui pemaparan lokasi safe haven peredaran yaba / ATS seperti di Dhaka dan Chittagong.

\section{Dhaka}

Keberadaan safe haven peredaran yaba / ATS ditengarai berada di kota Dhaka, tepatnya di sekitar flyover (jalan layang) Hanif. Flyover Hanif diketahui menjadi salah satu titik aktivitas peredaran serta transaksi yaba / ATS sepanjang siang dan malam dengan berbagai kalangan diketahui berkumpul di titik tersebut untuk melakukan transaksi dan konsumsi dengan menyamar sebagai pemulung (Rahman, 2016). Meskipun lokasi ini banyak diketahui serta dianggap meresahkan, otoritas keamanan diketahui membiarkan tempat ini karena sulitnya pemberantasan aktivitas peredaran di tempat tersebut yang sangat intens (Rahman, 2016). Indikasi kota Dhaka sebagai safe haven peredaran yaba / ATS diperkuat oleh jumlah kasus terkait aktivitas tersebut pada tahun 2015-2017 yang mencatat angka sebanyak 554, 1641, serta 2310 kasus yang merupakan rentetan kasus terbanyak dari seluruh provinsi Bangladesh (DNC, 2017).

\section{Chittagong}

Keberadaan safe haven peredaran yaba / ATS lainnya diketahui berada di kota Chittagong, tepatnya di sekitar kampus Chittagong University serta sejumlah infrastruktur di sekitarnya (Masum, 2017). Aktivitas peredaran yaba / ATS diketahui berjalan pada pagi sampai malam hari dengan leluasa dan menarik banyak kalangan melakukan aktivitas peredaran sampai transaksi tanpa halangan dari pihak penegak hukum (Masum, 2017). Indikasi kota Chittagong sebagai safe haven peredaran yaba / ATS diperkuat oleh jumlah kasus tersebut tahun 2015-2017 yang mencatat angka 366, 1096, dan 1809 kasus yang menjadikan Chittagong sebagai provinsi terbanyak yang mencatat kasus terkait yaba setelah Dhaka (DNC, 2017).

diketahui indeks bebas korupsi di Bangladesh tahun 2015-2017 termasuk salah satu yang terendah dari sejumlah negara di dunia dengan perolehan indeks secara berturut-turut mencapai 0,27 pada 2015(World Justice Project, 2015) lalu 0,34 pada 2016 (World Justice Project, 2016) serta 0,35 pada 2017 (World Justice Project, 2018). Melalui perolehan indeks bebas korupsi yang mempunyai skala 0-1 perolehan indeks tersebut menunjukkan tingkat 
korupsi yang tinggi di Bangladesh. Temuan ini sejalan dengan aktualisasi safe baven peredaran yaba / ATS di Dhaka dan Chittagong seiring perolehan data absence of corruption tersebut diperoleh melalui survei dari 3 provinsi terbesar Bangladesh termasuk Dhaka dan Chittagong (World Justice Project, 2018). Sehingga preposisi aktivitas TOC cenderung menciptakan safe haven dalam menjalankan aktivitasnya yang ditandai keberadaan korupsi sistemis aparatur negara adalah benar. Preposisi tersebut berhasil dipenuhi sehingga keberadaan lokasi safe haven dalam aktivitas peredaran yaba / ATS di Bangladesh beserta indikasi keberadaan korupsi sistemis di dalamnya sebagai risk prevention memengaruhi peningkatan peredaran narkotika jenis yaba / ATS di Bangladesh tahun 2015-2017.

\section{Defensive Measures}

Parameter defensive measures ditandai dengan kriteria keberadaan aktivitas counterintelligence dalam aktivitas TOC (Williams \& Goodson, 2002). Berdasarkan temuan penelitian diketahui aktivitas peredaran yaba / ATS di Bangladesh tahun 2015-2017 menggunakan sejumlah cara counter-intelligence sehingga memenuhi kriteria defensive measures. Hal ini dapat dibuktikan melalui paparan aktivitas counter-intelligence seperti teknologi transportasi dan keterlibatan institusi formal.

\section{Penggunaan Teknologi Transportasi}

Penggunaan counter-intelligence melalui teknologi mode transportasi diketahui menggunakan kapal nelayan pencari ikan serta garam yang bergerak dari perairan Malayshil dekat perbatasan Bangladesh-Myanmar menuju sejumlah perairan sungai seperti Wekyong, Thiangkali, Pathargata di Barguna, Mahirpur di Kuakata, Bhola, dan Dhaka (Hasan, 2019). Melalui rute ini muatan yaba / ATS yang disembunyikan dalam kapal-kapal tersebut diedarkan ke seluruh wilayah Bangladesh (Hasan, 2019). Otoritas keamanan Bangladesh dikabarkan berhasil mengamankan sejumlah 450.000-2000.000 pil yaba melalui kapal nelayan dan garam yang melintasi rute tersebut sepanjang 2016-2017 (Hasan, 2019) Penggunaan mode transportasi kedua dilakukan dengan memanfaatkan truk dengan nama maskapai bisnis untuk mengedarkan yaba dari perbatasan Bangladesh-Myanmar. Hal ini terungkap pada tahun 2016 di mana sejumlah truk dengan nama maskapai seperti New Al Amin Transport Agency dan New Shimul Transport Agency di Chittagong berhasil diamankan dengan 90.000 butir yaba / ATS (Rahaman, 2016). Kasus selanjutnya terjadi di Dhaka dengan sebuah truk berisi 70.000 butir yaba / ATS dengan nama Ramesh Sarkar Electronics yang berhasil diamankan dengan di mana nama perusahaan tersebut terbukti fiktif (Rahaman, 2016).

\section{Keterlibatan Oknum Institusi Formal}

Aktivitas peredaran yaba / ATS pada tahun 2015-2017 juga diketahui melibatkan oknum institusi formal merujuk pada keterlibatan oknum kepolisian berpangkat subinspektur dari Special Branch sebagai tokoh pengedar dengan berbagai relasi di sekitarnya yang juga anggota kepolisian serta staf pengadilan tinggi (High Court) (Khan, 2015). Di samping itu keterlibatan oknum institusi formal lainnya ditunjukkan dengan anggota Dewan Kota dari Bogra bernama Abdul Matin (Huda, 2017), sampai dengan oknum militer di wilayah perbatasan Bangladesh-Myanmar yaitu Shihab Uddin dan Shafiqul Islam (Hussain, 2017). 
Selanjutnya penulis melakukan verifikasi temuan penelitian dalam studi kasus penulis terhadap preposisi dalam parameter defensive measures yakni aktivitas TOC cenderung menjalankan aktivitasnya melalui cara- cara counter-intelligence untuk memperkecil risiko menghadapi penegakan hukum (Williams \& Goodson, 2002). Melalui verifikasi temuan penelitian yang dilakukan maka preposisi aktivitas TOC cenderung menggunakan cara-cara counter-intelligence untuk memperkecil penegakan hukum adalah terbukti benar. Preposisi ini berhasil dipenuhi sehingga kondisi keberadaan aktivitas counter-intelligence dalam aktivitas peredaran yaba / ATS di Bangladesh seperti penggunaan teknologi transportasi dan keterlibatan oknum institusi formal sebagai defensive measures memengaruhi peningkatan peredaran narkotika jenis yaba / ATS di Bangladesh tahun 2015-2017 seiring keberadaan cara-cara counter- intelligence menunjukkan bagaimana posisi aktor TOC terutama aktor peredaran yaba / ATS yang bergerak semakin advanced dalam menghadapi bentuk-bentuk upaya penegakan hukum yang dilakukan Pemerintah Bangladesh dan di saat bersamaan membuat aktivitas TOC dapat bergerak secara leluasa melalui cara-cara tersebut.

\section{Mitigation Measures}

Parameter mitigation measures ditandai dengan kriteria keberadaan cara-cara penyembunyian (concealment) terkait aktivitas TOC (Williams \& Goodson, 2002). Melalui temuan penelitian aktivitas peredaran yaba / ATS di Bangladesh tahun 2015-2017 diketahui menggunakan cara-cara concealment sehingga memenuhi kriteria mitigation measures. Hal ini dapat dibuktikan melalui aktivitas concealment seperti penggunaan kapal nelayan dan rute baru serta penyembunyian lewat kamp pengungsi Rohingya.

\section{Hybird Model (Transnational) Opportunity}

Parameter opportunity ditandai oleh kriteria keberadaan kondisi negara yang mendukung aktivitas TOC atau kejahatan transnasional (Williams \& Goodson, 2002). Melalui temuan penelitian Bangladesh diketahui memiliki crime rate tinggi dan law enforcement rendah sehingga dikategorikan sebagai weak state dan memenuhi kriteria opportunity. Hal ini dibuktikan dengan temuan data terkait seperti data kriminalitas di Bangladesh, tingkat homicide , pernyataan Kedubes AS di Bangladesh serta indeks penegakan hukum Bangladesh yang serupa dengan data dalam parameter weak state. Melalui Tabel 3 yang bersumber dari Bangladesh Police diketahui angka crime rate di Bangladesh 2015-2017 berada dalam kisaran cukup tinggi Angka kasus kriminalitas tersebut meliputi berbagai bentuk aktivitas kriminal seperti dacoity (perampokan bersenjata oleh kelompok/geng) sampai dengan penyelundupan (Bangladesh Police, 2017). Indikasi crime rate tinggi di Bangladesh diperkuat oleh data tingkat homicide yang terjadi tahun 2015-2017 di Bangladesh pada Tabel 4 (World Bank, n.d.-c). Melalui tabel tersebut diketahui rata-rata tingkat homicide di Bangladesh adalah 2,30. Angka tersebut berada di bawah rata-rata negara kawasan Asia Selatan yakni 2,59 yang apabila diurutkan maka Bangladesh masih berada di atas angka rata-rata negara seperti India, Bhutan, Maladewa dan Nepal (data ditulis 0 karena sejauh berlangsungnya penelitian belum dapat diketahui) meskipun berada di bawah Afghanistan, Pakistan dan Sri Lanka. Indikasi selanjutnya dibuktikan dengan pernyataan Kedubes AS di Bangladesh yang mengategorikan crime rate di Bangladesh ke dalam level high (OSAC, 2017). 
Selanjutnya indikasi rendahnya law enforcement rate di Bangladesh tahun 2015- 2017 dibuktikan melalui data law enforcement rate dari World Justice Project (World Justice Project, 2018) yang dapat dilihat pada Tabel 5. Melalui tabel tersebut diketahui rendahnya law enforcement rate di Bangladesh pada tahun 2015-2017 yang ditunjukkan melalui skala nilai 0-1 (World Justice Project, 2018). Bangladesh memperoleh nilai 0,33 pada 2015, (World Justice Project, 2015) 0,33 (2016), (World Justice Project, 2016) dan 0,34 (2017) (World Justice Project, 2018). A pabila mengacu pada skala nilai 0-1 maka law enforcement rate Bangladesh yang memperoleh nilai 0,33-0,34 sepanjang 2015-2017 terindikasi rendah. Selanjutnya penulis memverifikasi temuan penulis terhadap preposisi aktivitas TOC cenderung bersifat transnasional dalam jangkauannya sebagai dampak dari globalisasi (Williams \& Goodson, 2002). Melalui temuan penelitian diketahui aktivitas peredaran yaba / ATS di Bangladesh bergerak secara transnasional sebagaimana temuan peredaran yaba berasal dari wilayah Shan State di Myanmar menuju Bangladesh serta tidak hanya melibatkan entitas lokal Bangladesh melainkan juga entitas lintas batas negara seperti warga Rohingya dari Myanmar yang berdiaspora ke Bangladesh.

\section{Motivation}

Parameter motivation ditandai dengan kriteria keberadaan krisis ekonomi yang terjadi di wilayah yang mendorong aktivitas TOC. (Williams \& Goodson, 2002). Melalui temuan penelitian diketahui Bangladesh tidak mengalami krisis ekonomi 89omestic tahun 2015-2017 sehingga tidak memenuhi kriteria opportunity. Hal ini dilihat dari sejumlah indikator yang secara umum dapat digunakan untuk melihat krisis ekonomi suatu negara seperti tingkat kemiskinan, tingkat inflasi, tingkat pengangguran, dan jumlah penduduk. Dalam tingkat kemiskinan Bangladesh diketahui memperoleh indikasi tingkat kemiskinan yang menurun dengan tercatat mendapatkan persentase sebesar 14,8\% (2016) yang meningkat daripada persentase sebelumnya yakni sebesar 19,6\% (2010) (World Bank, n.d.-e). Untuk tingkat inflasi Bangladesh terindikasi menurun dari persentase sebesar 6,914\% (2015), 5,514\% (2016) serta 5,702\% (2017) (World Bank, n.d.-b). Dalam unemployment rate Bangladesh secara umum terindikasi mengalami unemployment rate yang menurun. Unemployment rate di Bangladesh tahun 2015-2017 bergerak fluktuatif yakni sebesar 4,42\% (2015), 4,35\% (2016), dan 4,37\% (2017) (CEIC, n.d.). Angka unemployment rate di Bangladesh pada 2017 diketahui naik tetapi masih jauh lebih kecil dari angka unemployment rate pada 2015. Sehingga tingkat unemployment rate di Bangladesh tahun 2015-2017 tidak signifikan atau relatif rendah.

Dalam total populasi Bangladesh diketahui terindikasi mengalami peningkatan populasi yakni sebesar 156.256.276 (2015), 157.970 .840 (2016) serta 159.670 .593 (2017) (World Bank, n.d.-d). Sedangkan GDP per kapita masyarakat Bangladesh tahun 2015-2017 diketahui justru meningkat dengan U\$D 1.248 .453 (2015), U\$D 1.401.621 (2016), U\$D 1.563.994 (2017) (World Bank, n.d.-a). Kondisi ekonomi Bangladesh yang secara umum positif dan tidak terindikasi mengalami krisis ekonomi turut diperkuat pernyataan IMF dalam laporan tersebut. Melalui sejumlah indikasi ini seperti poverty rate, inflation rate dan unemployment rate yang menurun serta population rate dengan GDP per capita yang terindikasi meningkat maka diketahui bahwa Bangladesh tidak terindikasi mengalami krisis ekonomi pada tahun 2015-2017. Sehingga kriteria parameter motivation belum berhasil dipenuhi sekaligus preposisi parameter ini belum berhasil dibuktikan yang membuat kondisi Bangladesh yang tidak 
terindikasi mengalami krisis ekonomi tidak memengaruhi peningkatan tren peredaran narkotika jenis yaba / ATS di Bangladesh tahun 2015-2017.

Resources

Parameter resources ditandai oleh kriteria keberadaan ikatan / relasi etnis dan diaspora dalam aktivitas TOC (Williams \& Goodson, 2002). Melalui temuan penelitian aktivitas peredaran narkotika jenis yaba / ATS di Bangladesh tahun 2015-2017 diketahui memiliki keberadaan ikatan etnis atau diaspora sehingga memenuhi kriteria parameter resources. Hal ini dapat dibuktikan melalui temuan penelitian penulis sebagaimana digunakan dalam parameter ethnic network yang dapat dilihat kembali dalam Tabel 9. Sehingga dalam aktivitas peredaran narkotika jenis yaba / ATS di Bangladesh tahun 2015-2017 diketahui terdapat keterlibatan etnis Rohingya melalui jumlah kasus (cases) serta penangkapan (arrest). Dalam Tabel 9 diketahui etnis Rohingya mencatat 86 kasus dengan jumlah arrest 290 orang (2015), 70 kasus dengan jumlah arrest 139 orang (2016), serta 104 kasus dengan jumlah arrest 224 orang (2017) yang menunjukkan ikatan etnis dan diaspora Gambaran ikatan relasi etnis dan diaspora ini diperkuat oleh beberapa literatur seperti The Rohingya in South Asia: People without a State, serta Marriage and Sexual and Reproductive Health of Robingya Adolescents and Youth in Bangladesh: a Qualitative Study yang menjelaskan kesamaan dialek bahasa masyarakat Bangladesh di kota seperti Chittagong (Chaudury \& Sammadar, 2018) dengan Rohingya dan kesamaan bahasa yang mencapai 70\% (ISCG, 2018).

Selanjutnya penulis memverifikasi temuan penelitian dengan preposisi aktivitas TOC cenderung berkembang di negara yang memiliki jumlah migran dari luar yang relatif tinggi (Williams \& Goodson, 2002). Melalui verifikasi ini diketahui Bangladesh sebagai negara dengan jumlah migran dari luar negeri relatif besar sepanjang tahun 2015-2017 terutama sebagai destinasi eksodus migran dari Myanmar. dengan rincian sebanyak 125.000292140.000(OCHA, 2015) pada 2015, 69.000294-500.000 (Giordana, 2017) (2016), serta 655.000(UNICEF, 2017)-720.000 (2017) (ISCG, 2018) Jumlah tersebut diindikasikan sebagai jumlah yang tinggi mengacu rincian jumlah migran ke negara lainnya terutama Rohingya ke negara lain pada 2017 seperti Arab Saudi (200.000), Pakistan (350.000), atau India (40.000) (Giordana, 2017).

Sehingga preposisi aktivitas TOC cenderung berkembang di negara yang memiliki jumlah migran dari luar yang relatif tinggi adalah benar. Preposisi ini berhasil dipenuhi sehingga keberadaan ikatan etnis-diaspora serta jumlah migran yang relatif tinggi di Bangladesh dibandingkan negara Asia Selatan lainnya seperti India dan Pakistan memengaruhi peningkatan peredaran narkotika jenis yaba / ATS di Bangladesh tahun 20152017. Seiring keberadaan aktualisasi keberadaan relasi multietnik dan diaspora terkait aktivitas TOC yaitu peredaran yaba / ATS yang kompleks ini menunjukkan bagaimana adanya aspek kultural yang selanjutnya memfasilitasi berjalannya aktivitas ini secara lintas batas negara.

\section{Hybird Model (Transshipment)}

Vulnerable State

Parameter vulnerable state ditandai dengan kriteria tingkat korupsi (corruption rate) tinggi dan kondisi instabilitas (instability) domestik negara (Williams \& Goodson, 2002). Melalui temuan penelitian maka diketahui Bangladesh sebagai vulnerable states dengan corruption rate 
tinggi dan kondisi instabilitas (instability) sehingga memenuhi kriteria vulnerable state. Hal ini dapat dibuktikan melalui Tabel 11 yang berisikan data laporan World Justice Project mengenai indeks bebas korupsi (absence of corruption) Bangladesh tahun 2015-2017. Dalam tabel tersebut Bangladesh diketahui menjadi salah satu negara dengan indeks terendah dari sejumlah negara lainnya di dunia dengan perolehan indeks mencapai 0,27 (2015),(World Justice Project, 2015) 0,34 (2016),(World Justice Project, 2016) serta 0,35 (2017) (World Justice Project, 2018). Melalui perolehan indeks bebas korupsi yang mempunyai skala penilaian 0-1 perolehan indeks tersebut menunjukkan corruption rate yang tinggi di Bangladesh. Selanjutnya kondisi instabilitas dalam domestik Bangladesh dapat dibuktikan melalui kasus kekerasan akibat kontestasi politik (political violence) dan pembunuhan di luar prosedur oleh aparat keamanan (extrajudicial killings) di Bangladesh yang relatif tinggi tahun 2015-2017 sebagaimana dapat dilihat pada Tabel 12 dan Tabel 13. . Dalam Tabel 12 diketahui Bangladesh pada tahun 2015 mencatat 375 kasus political violence, kemudian 350 kasus (2016) serta 337 kasus (2017). Apabila diamati tren kasus political violence di Bangladesh tahun 2015-2017 cenderung menurun. Akan tetapi meski menurun, dengan rata-rata kasus political violence yang mencapai 354 kasus sepanjang tahun 2015-2017maka kondisi tersebut menggambarkan tingkat political violence di Bangladesh yang relatif tinggi.

Tabel 12. Kasus Political Violence di Bangladesh Tahun 2015-2017

\begin{tabular}{|c|c|}
\hline TAHUN & Cases \\
\hline 2015 & 375 \\
\hline 2016 & 350 \\
\hline 2017 & 337 \\
\hline
\end{tabular}

Sumber: Annual Human Rights Report 2015-2017. (Odhikar, 2017)

Selanjutnya dalam Tabel 12 mengenai extrajudicial killings di Bangladesh pada 20152017 diketahui Bangladesh mencatat sebanyak 185 kasus pada 2015, selanjutnya sebanyak 178 kasus 2016 serta sebanyak 155 kasus 2017. Extrajudicial killings mengacu pada impunitas oleh aparat keamanan Bangladesh terhadap warganya yang terindikasi sebagai tokoh lawan politik dari partai berkuasa (Awami League/AL) seperti BNP dan Jamaat-e-Islami.310 Jumlah kasus extrajudicial killings di Bangladesh sepanjang 2015-2017 meski cenderung menurun akan tetapi masih mencatat rata-rata di atas 100 kasus.311 Sehingga tingkat extrajudicial killings di Bangladesh terbilang relatif tinggi.

Tabel 13. Data Extrajudicial Killings di Bangladesh Tahun 2015-2017

\begin{tabular}{|c|c|}
\hline TAHUN & Cases \\
\hline 2015 & 185 \\
\hline 2016 & 178 \\
\hline 2017 & 155 \\
\hline
\end{tabular}

Sumber: Statistics on Human Rights Violation 2015, Bangladesh Human Rights Report 2015-2017. (Odhikar, 2016b)(Odhikar, 2017).

Selanjutnya penulis memverifikasi temuan penelitian terhadap preposisi aktivitas TOC cenderung melakukan aktivitasnya di negara yang memiliki tingkat korupsi tinggi ataupun kondisi instabilitas.(Williams \& Goodson, 2002). Sehingga preposisi aktivitas yang berbunyi TOC cenderung melakukan aktivitasnya di negara yang memiliki tingkat korupsi tinggi adalah terbukti benar. Preposisi ini berhasil dipenuhi sehingga kondisi Bangladesh sebagai vulnerable states dengan corruption rate tinggi dan instabilitas memengaruhi peningkatan 
peredaran narkotika jenis yaba / ATS di Bangladesh tahun 2015-2017. Seiring kondisi corruption rate dan instability sebagaimana teori Phil Williams dan Goodson menunjukkan bagaimana lemahnya legitimasi atau kapasitas negara sehingga secara bersamaan menjadi tempat timbul dan berkembangnya aktivitas TOC seperti peredaran yaba / ATS di Bangladesh.

Sensitive States

Parameter sensitive states ditandai oleh kriteria berupa jumlah produk ekonomi (economy product) suatu negara yang rendah yang mendorong timbulnya impor skala besar dan mendorong berkembangnya aktivitas TOC (Williams \& Goodson, 2002). Melalui penelitian yang dilakukan penulis maka diketahui Bangladesh merupakan sensitive states dengan jumlah produk ekonomi yang relatif rendah, produk ekonomi Bangladesh dapat dilihat sangat bertumpu pada sektor readymade garments dengan persentase sebesar 89,95\% dan 88,73\%. Sedangkan jumlah produk lainnya seperti textile articles, textile fibre/yarn, footwear diketahui mencatat persentase hanya sebesar 3\%, shrimps/prawn sebesar 1,5\%, hides skins/leathers sampai dengan fertilizer antara 1\% sampai dengan $<1 \%$ (BBS, 2017). Dari data tersebut produk shrimps/prawn dapat menjadi produk disorot seiring Bangladesh sebagai negara dengan wilayah perairan tetapi produksi shrimp/prawn terhitung sedikit dan sektor perikanan tidak menjadi produksi ekspor. Indikasi rendahnya produksi produk ekonomi Bangladesh dapat dilihat melalui data impor Bangladesh terhadap negara yang ditengarai kuat menjadi asal peredaran yaba / ATS ke Bangladesh yaitu Myanmar pada tahun 2015-2017 (WITS, 2017). Penulis melihat tingkat ekspor-impor dari Myanmar ke Bangladesh seiring keterbatasan data ekspor-impor dari Bangladesh ke Myanmar yang banyak berhenti pada tahun 2015. Dalam tabel tersebut diketahui Bangladesh mengimpor banyak komoditas dari Myanmar meliputi raw materials, intermediate goods, consumer goods, animals, metals, dan woods.

\section{KESIMPULAN}

Kesimpulan yang dapat diperoleh penulis dari penelitian penulis menggunakan teori Model of Anticipating TOC yang ditulis oleh Phil Williams dan Roy Goodson adalah faktor politik, faktor ekonomi, faktor sosial budaya, faktor bybrid-transnational model, serta faktor bybrid-transshipment model memengaruhi peningkatan peredaran narkotika jenis yaba / ATS di Bangladesh tahun 2015-2017. Faktor politik meliputi kondisi Bangladesh sebagai weak states dan memiliki keberadaan konflik etnis dan terorisme, faktor ekonomi (economic model) dengan permintaan pasar dan profit besar terkait yaba / ATS sampai faktor sosial budaya (social model) dengan keberadaan ikatan keluarga- patron klien, ikatan etnis-diaspora dan ikatan institusi formal terkait aktivitas peredaran yaba / ATS.

Kemudian dilanjutkan oleh faktor strategis (strategic model) dengan penggunaan safehaven, cara counter-intelligences dan cara concealment dalam aktivitas peredaran yaba / ATS, faktor bybrid-transnational model dengan kondisi Bangladesh sebagai weak state disertai ikatan-etnis diaspora terkait aktivitas peredaran yaba / ATS dan faktor bybrid-transshipment model dengan kondisi Bangladesh sebagai vulnerable state sekaligus sensitive state. Selanjutnya diketahui bahwa faktor ekonomi, faktor sosial budaya, faktor strategis dan faktor bybrid transshipment merupakan faktor dominan yang memengaruhi peningkatan peredaran narkotika jenis yaba / ATS di Bangladesh tahun 2015-2017.

\section{DAFTAR PUSTAKA}

Advisory Commision on Rakhine State. (n.d.). Final Report of the Advisory Commission of Rakbine State. 
Ahmed, I., \& Liton, S. (2018). Yaba Invasion-1: Hostage to Myanmar. Retrieved November 24, 2019, from The Daily Star website:

https://www.thedailystar.net/frontpage/hostage-myanmar-1575205

Asia News Network. (2016). Biggest Ever Yaba Haul in Bangladesh. Retrieved May 10, 2019, from Asia News Network website:

http:/ / annx.asianews.network/content/biggest-ever-yaba-haul- bangladesh-7783

Azis, A. (2019). Ready to Surrender Top Yaba Saiful in Police Custody. Retrieved October 29, 2019, from Dhaka Tribune website: https://www.dhakatribune.com/bangladesh/nation/2019/05/29/yaba-kingpinsaiful-in-police-custody

Bangladesh Police. (n.d.). Strategic Plan 2018-2020.

Bangladesh Police. (2015). Bangladesh Police Crime Statistics 2015.

Bangladesh Police. (2016). Bangladesh Police Crime Statistics 2016. Retrieved October 25, 2019, from Bangladesh Police website: https://www.police.gov.bd/en/crime_statistic/year/2017

Bangladesh Police. (2017). Bangladesh Police Crime Statistics 2017. Retrieved October 25, 2019, from Bangladesh Police website: https://www.police.gov.bd/en/crime_statistic/year/2017

BBC News. (2019). Bangladesh Country Profile. Retrieved January 17, 2019, from BBC News website: https://www.bbc.com/news/world-south-asia-12650940

BBS. (2017). Bangladesh Statistics 2017.

Britannica. (n.d.). Diaspora.

Business Standard. (2018). Yaba Drug Smuggling Addiction Record Alarming Rise in Bangladesh.

CEIC. (n.d.). Bangladesh Unemployment Rate.

Chaudury, S. B. R., \& Sammadar, R. (2018). The Rohingya in South Asia: People without a State (1st ed.). Oxon: Routledge. Retrieved from https://www.routledge.com/The-

Rohingya-in-South-Asia-People-Without-a-State/Chaudhury-

Samaddar/p/book/9781138611016

CLGF. (2017). The Local Government System in Bangladesh.

Daily Asian Age. (2015). Ctg Major Route for Illegal Drug, Yaba Smuggling. Retrieved November 7, 2019, from Daily Asian Age website: https:/ / dailyasianage.com/news/2188/ctg-major-route-for-illegal-drug- yabasmuggling

Dhaka Tribune. (2017a). Inu: The Rohingyas are Making Chittagong an Economic Zones of Drug. Retrieved November 6, 2019, from Dhaka Tribune website: https://www.dhakatribune.com/bangladesh/crime/2017/12/05/inu-chittagongdrug-zone

Dhaka Tribune. (2017b). Stateless Rohingya Refugees Sucked into Bangladesh Booming Drug Trade. 
DNC. (2013). Annual Drug Report Bangladesh 2013.

DNC. (2015). Annual Drug Report Bangladesh 2015.

DNC. (2016). Annual Drug Report Bangladesh 2016. Retrieved January 17, 2019, from Bangladesh Department of Narcotics Control (DNC) website: www.dnc.gov.bd/site/view/annual_reports/

DNC. (2017). Annual Drug Report Bangladesh 2017.

France 24. (2017). Burma Seizes 20 Million Pills in Golden Triangle Drug Bust. Retrieved September 2, 2019, from France 24 website: https://www.france24.com/en/20170810-burma-seizes-20m-pills- golden-triangledrug-bust-thailand

Giordana, E. (2017). Behind the Rohingya Diaspora a Story that Began 200 Years Ago. Retrieved November 4, 2019, from Reset Dialogues website: https://www.resetdoc.org/story/behind-rohingya-diaspora-story-began-200- yearsago/

Hasan, K. (2019). Smugglers are Now Using Unprotected Rivers to Transport Yaba Consignments.

Huda, N. (2017). Municipal Councillor Held with Yaba in Bogra. Retrieved November 7, 2019, from Dhaka Tribune website:

https://www.dhakatribune.com/bangladesh/crime/2017/06/08/municipalcouncillor-yaba-bogra

Hussain, A. (2017). 2 Army Privates Privates Detained with 50.000 Yaba Pills.

Internal Drug Policy Consortium. (n.d.). South Asia.

ISCG. (2018). Marriage and Sexual and Reproductive Health of Rohingya Adolescents and Youth in Bangladesh: a Qualitative Study, Population. Retrieved November 4, 2019, from Population Council website:

https://www.popcouncil.org/uploads/pdfs/2018PGY_RohingyaResearchReport.pdf

Islam, R. N., Tabassum, N. E., Shafiuzzaman, A., Umar, B. U., \& Khanam, M. (2013). Methamphetamine (YABA) Abuse: A Case Study in Young Male. Faridpur Medical College Journal, 7(2), 102-104. https:// doi.org/10.3329/fmcj.v7i2.13527

Kaladan Press. (2015). BGB Return 514 Rohingya to Burma in March. Retrieved September 3, 2019, from Burma News International website: https://www.bnionline.net/en/news/kaladan-press/item/448-bgb-return-514rohingya-to-burma-in-march.html

Khan, M. J. (2015). Policemen, Lawyers Involved in Yaba Trade. Retrieved November 7, 2019, from Dhaka Tribune website: https://www.dhakatribune.com/uncategorized/2015/06/21/rab- policemen-lawyersinvolved-in-yaba-trade

Khan, M. J. (2016). Inside the Yaba Trade. Retrieved October 23, 2019, from Dhaka Tribune website: https://www.dhakatribune.com/uncategorized/2016/01/29/insidethe-yaba-trade 
Khan, M. J. (2019). Indian Gangs Smuggling Yaba into Bangladesh. Retrieved October 28, 2019, from The Daily Star website:

https://www.thedailystar.net/backpage/news/indian-gangs-smuggling- yababangladesh-1788610

Khan, M. J., \& Jinnat, M. A. (2019). Yaba Trade in Cox Bazar: Situation Changes So Does Strategy. Retrieved September 28, 2019, from Daily Star website:

https://www.thedailystar.net/backpage/news/indian-gangs-smuggling- yababangladesh-1788610

Lewis, D., \& Hossain, A. (2019). Local Political Consolidation in Bangladesh: Power, Informality and Patronage. Development and Change.

https://doi.org/10.1111/dech.12534

Mahmud, T. (2017). Yaba Smugglers Entering Bangladesh in Disguise of Displaced Rohingyas.

Mahmud, T. (2018). From Myanmar to Bangladesh: Yaba's Journey of a Thousand Miles.

Masum, H. (2017). CU Campus a Safe Haven for Drug Addicts, Peddlers. Retrieved November 12, 2019, from The Independent website:

http://www.theindependentbd.com/post/129368

Mathieson, D. (2017). Drug Trade Obscure Myanmar's Rakhine State Violence. Retrieved September 3, 2019, from The Asia Times website:

https://www.asiatimes.com/2017/05/article/drug-trade-obscures-rakhine-stateviolence/

Mehtab, T., \& Rahman, A. (2018). From Parties to Residences How Yaba's Spreading Like Wildfire. Retrieved October 28, 2019, from Dhaka Tribune website: https://www.dhakatribune.com/opinion/special/2018/03/16/parties-residencesyaba-spreading-like- wildfire

Myanmar News Agency. (2016). Arakan Army Officer Arrested with Guns, Drugs, in Yangon. Retrieved September 2, 2019, from Global New Light of Myanmar website: https://www.globalnewlightofmyanmar.com/how-to- fund-a-war-arakan-armyofficer-arrested-with-guns-drugs-in-yangon/

Myat, M. M. (2018). New Strategies Needed as EAO's Adapt to Changes in Drug Demand. Retrieved August 14, 2019, from The Irrawady website: https://www.irrawaddy.com/opinion/guest- column/new-strategies-needed-eaosadapt-changes-drug-demand.html

OCHA. (2015). Humanitarian Bulletin Myanmar Issue 5 May/June 2015. Retrieved from https://reliefweb.int/sites/reliefweb.int/files/resources/Bulletin_Humanitarian_OC HA_May-Jun2015.pdf

Odhikar. (2015). Bangladesh Annual Human Rights Report 2015. Dhaka. Retrieved from http:/ / odhikar.org/annual-human-rights-report-2015-odhikar-report-on-bangladesh/

Odhikar. (2016a). Bangladesh Annual Human Rights Report 2016. Dhaka. Retrieved from http://odhikar.org/wp-content/uploads/2017/01/AHRR-2016_Eng.pdf

Odhikar. (2016b). Bangladesh Statistics on Human Rights Violation 2015. Retrieved November 17, 2019, from Odhikar website: http:/ /odhikar.org/wp- 
content/uploads/2016/01/Statistics_English_2015.pdf

Odhikar. (2017). Bangladesh Annual Human Rights Report 2017. Dhaka. Retrieved from http://odhikar.org/wp-content/uploads/2018/01/Annual-HR-Report2017_English.pdf

OSAC. (2017). Bangladesh 2017 Crime and Safety Report. Retrieved October 26, 2019, from US Department of State Safety Advisory Council website: https://www.osac.gov/Content/Report/38308f29-94d6-4165-bd2d-15f4ae0010fe

Quadir, S., \& Das, K. N. (2017). Bangladesh to Ban Cold Pill to Fight Meth Surge. Retrieved November 12, 2019, from Reuters website: https://www.reuters.com/article/us-bangladesh- drugs/bangladesh-to-ban-cold-pillchemical-to-fight-meth-surge-idUSKBN1691Y1

Rahaman, M. (2016). Transport Worker Behind Yaba Trading. Retrieved November 12, 2019, from Dhaka Tribune website: https://www.dhakatribune.com/bangladesh/2016/08/20/transport-workersbehind-yaba-trading

Rahman, K. N. (2016). Drug Addicts, Peddlers Find Safe Haven around Hanif Flyover in Dhaka. Retrieved November 12, 2019, from BDNews24 website: https://bdnews24.com/bangladesh/2016/01/09/drug-addicts- peddlers-find-safehaven-around-hanif-flyover-in-dhaka

Rashid, M., \& Iqbal, F. (2019). Badi’s Brother Running Drug Syndicate from Yangon.

Roy, S. (2018). Yaba: The Red Pills and The Rohingya. Retrieved December 9, 2019, from The Diplomat website: https://thediplomat.com/2018/06/yaba-the-red-pills-andthe-rohingya/

Rubel, W., \& Alamgir, N. U. (2019). 102 Cox Bazar's Yaba Dealers Surrender. Retrieved October 29, 2019, from Daily Sun Bangladesh website: https://www.thedailystar.net/frontpage/news/yaba-trade-coxs-bazar-situationchanges-so-does-strategy- 1693885

Saad, M., \& Rahaman, M. (2018). Yaba Godfathers: Out of Teknaf, into Safety. Retrieved October 29, 2019, from The Daily Star website:

https://www.thedailystar.net/frontpage/yaba- godfathers-out-teknaf-safety-1585462

Seefar. (n.d.). 6 Ideas for Interpreting Drug Seizures Data. Retrieved April 14, 2019, from Seefar website: https:/ / seefar.org/research/6-ideas-for-interpreting-drug-seizure-data

Sugiyono. (2011). Metode Penelitian Kuantitatif Kualitatif dan R\&D. Bandung: Alfabeta.

The Economist. (2017). The Economist Intelligence Unit: Democracy Index 2016. Retrieved October 27, 2019, from The Economist website: http:/ / felipesahagun.es/wp- content/uploads/2017/01/Democracy-Index-2016.pdf

The Economist. (2018). The Economist Intelligence Unit: Democracy Index 2017. Retrieved October 27, 2019, from The Economist website: https://pages.eiu.com/rs/753-RIQ- 438/images/Democracy_Index_2017.pdf

The Independent. (2019). Yaba Lord Saiful Among 3 Killed in Gunfights. Retrieved October 29, 2019, from The Independent website: 
http://www.theindependentbd.com/post/201852

The Irrawaddy. (2019). Analysis : Arakan Army -A Powerful New Threat to the Tatmadaw.

Retrieved September 2, 2019, from The irrawaddy website:

https://www.irrawaddy.com/news/burma/analysis-arakan-army-powerful-new-

threat-tatmadaw.html/amp

The Stateless Rohingya. (2015). Bangladesh a Breeding Ground for Rakhine Terrorists.

Retrieved September 1, 2019, from The Stateless Rohingya website:

https://www.thestateless.com/2015/08/bangladesh-a-breeding-ground-for-rakhineterrorists.html

Tun, C. M. (2017). Illicit Drug Seizes from Myanmar Army Privates in Maungdaw.

Retrieved December 9, 2017, from The Irrawady website:

https://www.irrawaddy.com/news/burma/illicit-drugs-seized- myanmar-armyprivates-maungdaw.html

Ullah, A. (2016). Yaba Traders Frequently Change Tactics to Dodge Law Enforcers.

Retrieved August 12, 2019, from Daily Sun Bangladesh website: https://www.dailysun.com/arcprint/details/128464/Yaba-traders-frequently-change-tactics-to-dodgelaw-enforcers/2016-04-14

UNICEF. (2017). UNICEF Bangladesh Humanitarian Situation Report No. 16-24 December 2017. Retrieved from https://reliefweb.int/sites/reliefweb.int/ files/resources/UNICEF Bangladesh Humanitarian Situ\%0Aation Report No.16 - 24 December 2017.pdf

UNODC. (n.d.). Transnational Organized Crime. Retrieved March 4, 2019, from United Nations Office on Drugs and Crime (UNODC) website: https://www.unodc.org/ropan/en/organizedcrime.htmlhttps://www.unodc.org/ropan/en/organized-crime.html

UNODC. (1995). Ninth United Nations Congress on the Prevention and the Treatments of Offenders. United Nations Office on Drugs and Crime (UNODC).

UNODC. (2006). World Drug Report 2006. Retrieved from https://www.unodc.org/pdf/WDR_2006/wdr2006_volume2.pdf

UNODC. (2011). Pattern and Trends of ATS and Other Drugs. United Nation Office on Drugs and Crime (UNODC).

UNODC. (2013). Global Smart Programme Regional Trends: South Asia 2013. United Nation Office on Drugs and Crime (UNODC). Retrieved from https://www.unodc.org/documents/southeastasiaandpacific/2013/11/ats2013/2013_Regional_ATS_South_Asia.pdf

UNODC. (2016). International Classification of Crime for Statistical Purposes 2016.

UNODC. (2017). World Drug Report 2017. Retrieved from https://www.unodc.org/wdr2017/field/Booklet_2_HEALTH.pdf

US Department of State. (2018). Report on Terrorism 2015-2017 Bangladesh. Retrieved November 30, 2019, from Refworld website: https://www.refworld.org/docid/5bcf1 fb6140.html 
Williams, P. (1998). Transnational Organized Crime and National and International Security : a Global Assesment. In Under Siege: Crime, Violence and Illegal Weapons. Halfway House. Retrieved from https://openlibrary.org/books/OL6830570M/Society_under_siege

Williams, P., \& Goodson, R. (2002). Anticipating organized and transnational crime. Crime, Law and Social Changne, 37, 311-355. https://doi.org/https://doi.org/10.1023/A:1016095317864

WITS. (2017). Myanmar Product Exports and Imports from Bangladesh 2015-2017.

World Bank. (n.d.-a). GDP Per Capita (Current US\$)-Bangladesh.

World Bank. (n.d.-b). Inflation Consumer Prices (Annual \%)-Bangladesh. Retrieved December 5, 2019, from Data World Bank website: https://data.worldbank.org/indicator/FP.CPI.TOTL.ZG?locations=BD

World Bank. (n.d.-c). Intentional Homicide (per 100.000 People). Retrieved October 26, 2019, from World Bank website: https:/ / data.worldbank.org/indicator/VC.IHR.PSRC.P5?end=2017\&locations=BDIN-LK-PK-MV-BT-AF\&start=2015

World Bank. (n.d.-d). Population Total-Bangladesh.

World Bank. (n.d.-e). Poverty Data.

World Justice Project. (2015). World Justice Project: Rule of Law Index 2015. Retrieved October 27, 2019, from World Justice Project website: https://worldjusticeproject.org/our- work/publications/rule-law-index-reports/wjprule-law-index-2015-report

World Justice Project. (2016). World Justice Project: Rule of Law Index 2016. Retrieved October 27, 2019, from World Justice Project website: https://worldjusticeproject.org/our- work/publications/rule-law-index-reports/wjprule-law-index ${ }^{\circledR}$-2016-report

World Justice Project. (2018). World Justice Project: Rule of Law Index 2017.

World Population Review. (2019). Bangladesh Population 2019. Retrieved March 5, 2019, from World Population Review website: worldpopulationreview.com/countries/bangladesh-population/ 